\title{
The Burden of a Child: Examining the Effect of Pregnancy on Women's Power in Ancient Egypt and Greece
}

\author{
SARA VARADHARAJULU ${ }^{1}$ \\ ${ }^{1} \mathrm{UCLA}$
}

September 12, 2020

\begin{abstract}
:
This paper explores the effect of pregnancy on women's access to power in ancient Greece and Egypt. It argues that the politico-economic institutions dictated the extent of a non-pregnant woman's power in these societies, and because of this, non-pregnant women in ancient Egypt were afforded more civil freedoms than those in Greece. However, in regards to determining the power of pregnant women, sociocultural influences, such as religion, played a much bigger role. Due to the Western, female-centric view of fertility in Greece, pregnant women were allocated significantly more ideological power than usual, which is evident in their ability to actively participate in their healthcare. On the other hand, the association of men with birth resulted in pregnant Egyptian women losing their preexisting political, economic, and sexual freedoms. Through the cross-cultural comparison of these two nations, it can be determined that the influence of pregnancy depends entirely on cultural infrastructure of a country.
\end{abstract}

\section{The Burden of a Child: Examining the Effect of Pregnancy on Women's Power in Ancient Egypt and Greece}

In the ancient world, parturition was considered to be a sacred phenomenon. The overlap of medicine, myth, and magic associated with childbirth differentiated pregnant women from other members and granted them a unique status in society. The fascination around pregnancy is perhaps best encapsulated by the use of various rituals to enhance fertility, conception, and parturition. It has been shown that ancient Greek women often referred to calendars to identify the optimal environmental circumstances for conception.[1] In addition, many women and priestesses belonging to the cults of goddesses such as Artemis or Demeter engaged in rituals to enhance fertility.[2] At the sanctuary of Artemis at Brauron, there is evidence that garments were donated to the goddess by women who had given birth or on behalf of those who had died during childbirth.[3] Garments were popular, and amongst the most luxurious, gifts, signifying that the ancients were willing to spend riches on pregnancy related matters. In ancient Egypt, fertility tests were performed by placing a clove of garlic in the vaginal region; since the womb was thought to be connected to the alimentary canal, Egyptians believed that the scent of garlic could be detected on the breath of a fertile woman. [4] In addition, various ceremonies were performed to earn the assistance of the birthing deities including Hathor, Isis, and Neith; in labor, the women was placed in a "house of birth" [5] that connected to the temples of the goddesses.

The diverse efforts devoted by the ancient Egyptian and Greek societies to exploring and improving the pregnancy process signifies its importance in their sociocultural structures. This paper examines the types of social power associated women and pregnant women in ancient Egypt and Greece. By comparing and contrasting their social and legal standings as well as the impact of social, cultural, political, and economic forces on these standings, it aims to identify the effect on pregnancy on women's statuses, and more specif- 
ically, power in society. To better clarify the meaning of "power", sources will be read through the lens of Mann's well-regarded IEMP model, which is discussed in detail below.[6]

While there are numerous similarities between the two societies, the distinguishing factor between nonpregnant women in Egypt and Greece is the access to political and economic power. While women were officially considered citizens in both states, the politico-economic structure of Egypt enabled women to legitimize their citizenship with formal monetary and governmental contributions while that of Greece prevented women from fully participating in public life. However, pregnancy changes the ideological power allocation in these societies. The sociocultural differences, in particular, religious rituals and myths and social practices, between the states resulted in women in Greece gaining some ideological power during pregnancy while women in Egypt were somewhat stripped of their pre-existing autonomy.

\section{Mann's Sources of Social Power: Ideological Power Drove the Ancient World}

Mann defines power, in its most general sense, as "the ability to pursue and attain goals through mastery of one's environment." [7] Power arises from the human need to chase individual goals, and therefore, create networks of social interactions to obtain these goals. These networks, also referred to as four primary sources of social power in Mann's IEMP model, have distinct capabilities and boundaries. It is the combination of these sources, in particular the utilization of the intensive and extensive power they possess, that drives human achievement.

This particular model was chosen because it has been cited frequently in the literature, for example, as a scheme that "comprehensively [clarifies] the power situation at the macro-level".[8] In addition, Mann's focus specifically on the ancients lends well to this paper, as it is well recognized that the sources of power driving major changes in the world alternate through the centuries. With regards to the ancient world, it is postulated that ideological power was the dominating network, as it was a time when religion and its associated "emotional/ritual techniques of solidarity and impressiveness" [9] spread. Mann's model provides the framework to compare and contrast the freedoms given to and limitations placed on women in the ancient world. For those unfamiliar with the model, its facets will be explored in depth in this section.

The first of these powers is ideological, the power of belief. This belief can be personal or institutionalized, such as with religious authority, and is entirely faith based. Its unprovable nature is best conveyed, "You cannot argue with a song." [10] Mann proposes that this power stems from the ability to monopolize norms, meaning, aesthetic/ritual practices and from the claim to knowing what is "right" and just. Although the knowledge of ideological power cannot be proven, its message does not have to be false or manipulative; most successful ideological movements contain rational, legitimate messages. While religion is an obvious example of ideological power, secular movements, such as Marxism, can be just as influential.

In stark contrast, economic power, simply put, is the access to resources. More specifically, it relies on one's capacity to control the production, distribution and consumption of goods, thereby effectively inserting oneself into the consumer relationship as a middle man. Marxists often focus on production as being the ultimate source of power because labor precedes the other parts of the chain. Mann also proposes that economic power is frequently dispersed and might not directly correlate with a hierarchical class structure, although it can.

According to Mann, though, the most coercive, concentrated form of power is military strength, or the mobilization of violence. While commonly thought of as the utilization of force during wartime, violent forms of social control, such as slavery, are subsections of military power that exist during peacetime. In direct contrast to political power, which will be discussed below, military influence has an extensive reach even outside of state borders. Mann gives the example of a local tribe which still continues to supply an annual tribute to its conquerors despite the fact that the nearest military base might be over 300 kilometers away.

Finally, Mann presents political power as the institutionalized regulation of society, or, in other words, state power. Unlike the other sources of power in IEMP, political power is contained within a society and is 
constrained by its borders. This limitation of power can be observed in the variable influence of a teacher. External to a teacher's power sphere, ie: school, his political power as an instructor ceases to exist, which is why he cannot assign homework if encountered at a grocery store. Also, in contrast to the rest of the power sources, political power relies on a "center" and falls with only a particular group or subsection of a group.

Throughout the remainder of the paper, these identified sources of power will be referenced. In addition, the sources and consequences of sexual power, which was added to this existing model by later historians, will be discussed.

\section{The Legal Statuses of Women in Ancient Greece and Egypt Differ}

From the analysis of the earliest available art, archeological, and textual records, it can be interpreted that the legal status of women in Egypt was equivalent to that of men.[11] Both men and women were able to purchase and sell property, which allowed women the chance to accumulate economic power. The ownership rights of Egyptian women are best communicated by an engraving on the Statue of Nakht-mut, a sculpture from the Third Intermediate Period of Egypt, 1070-664 BC. (Figure 1).[12] Mut was considered to be the mother goddess of Thebes; her double crown is thought to represent her rule over both Upper and Lower Egypt.[13] The statuette reads, "Act excellently for our daughter... Let her seize this property and kill anyone who will trespass against her!" [14] Not only is the woman's right to ownership so fierce that she can "seize" the property, but it is so great that she may "kill" to defend it. In the legal arena, both sexes could initiate court cases or be sued by others. Women were responsible for their own civic actions and although it was rare, they could serve as witnesses in a court case or for legal documents and sit on juries.[15] The extent of women's full legal rights was manifested in her ability to initiate divorce and opportunity to remarry thereafter.[16]

This legal equality of the sexes most likely stems from political and economic structure of Egypt. Egypt functioned as a theocratic monarchy; the king was viewed as an intermediary to the gods and his laws as manifestations of the gods' wills. [17] The political power of the state was concentrated in him, and to some extent, the royal family, which prevented any group of civilians, such as upper-class males, from gaining an advantage over others.[18] This allowed for political power to be somewhat evenly distributed among citizens. In addition, because Egypt was not an empire but rather a contained state[19], women were able to contribute to the economy, which also granted them economic power.

The economic and political power of women in Egypt is evident in a section of the instructions of Ptahhotep. Ptahhotep was a vizier, essentially a first minister, during the Fifth Dynasty of Egypt, which spanned from the late $25 \mathrm{BC}$ to early $24 \mathrm{BC}$. Also known as the Maxims of Ptahhotep, this novel belongs to the sebayit "instruction" genre, filled with "perspicacious advice" [20] regarding a variety of topics from table manners to beauty tips for one's spouse. Ptahhotep's guidance was "reworked" [21] into a literacy collection that was often read by young men from influential families as a guide for how to live an ordered, harmonious life.[22] One particular passage from his work revolves around advice concerning how to take care of one's wife; surprisingly, it also alludes to the power women possessed - men needed to "restrain" [23] women from exercising their power. The author goes so far as to compare a woman's eye to a "storm," [24] indicating the supposed wild powers of females. One of the lines specifically warns not to "contend with her in court," [25] which implies that women held legal power and were willing to fight for their rights. This text suggests that women were feared politically because of the legal autonomy they possessed.

In stark contrast, women in Greece were severely restricted legally. Although they were official citizens, it can be argued that their citizenship was merely a formality to legitimize the citizenship of their male offspring.[26] In reality, they were legal minors. Although a man was called a polites, citizen, a woman was never referred to by this name; instead she was dubbed an aste, a woman belonging to the city, or an Attike gune (Attic women/wife).[27] Athenian women were excluded from the so-called "democracy" [28] — they were denied the right to attend assembly, serve on the council, or vote. While the Athenians justified the political equality of free men by the fact that they were all direct descendants of the demigod Erichthonios[29], there is no mention of women in the myth, hence reason to deny them political equality.[30] Instead, the race of women, 
genos gunaikon, was thought to be derived from Pandora, who was a punishment Zeus created for mankind. In the Theogony, Hesiod describes women to be "wicked" and a "nagging burden" for men; he even asserts that women are simply an "evil for mortal men".[31] In stark contrast to the men who are metaphorically portrayed as the ever-hardworking "busy" bee, woman are depicted as "drones" who "cram their bellies full of what others harvest." [32] From this passage, it can be assumed that the supposed laziness and plethora of vices women possessed were considered justification to deprive them of the benefits of citizenship.

However, the exclusion of women from public life extends far beyond the political sphere. Women were considered to be a part of the oikos, household, signifying that she was excluded from the public sphere.[33] Their exclusion was taken so seriously in fact that the names of wives and daughters were not even directly mentioned in legal speeches.[34] This mentality is clearly visible in Pericles' Funeral Oration as he speaks about the excellence of women. He states that a wife's "glory is great... if there is the least possible talk of [her] among men either for praise or blame." [35] Because of their diminished legal status, women required a kyrios, a male guardian who was either her husband or the closest male relative, to manage all legal transactions on her behalf. The kyrios handled everything from providing a dowry to litigating in courts, which is a sharp contrast to Egyptian women who could initiate court cases themselves.[36] In addition, the kyrios was required to accompany them in public on the limited occasions when they were allowed to venture outside the house.[37] Women also could not own property independently, thereby depriving them of an opportunity to amass wealth and gain an economic advantage.[38]

\section{The Similar Social Standings of Ancient Egyptian and Greek Women}

Although women possessed political power in Egypt, the social status of women was widely different than their designated legal status. Ancient texts show that while men were differentiated by their professions or income, women were usually referred to as "Mistress of the House" [39] because they rarely held jobs outside the domestic sphere. In addition, women were frequently referred to through the names and titles of either their husbands or fathers, showing that with regards to a social name, they were considered to be dependent.[40] Due to this, a large portion of their social identity was tied to the status of their husband. This fact is evident in "The Instructions of Any", a didactic text from the New Kingdom[41], which states that "A woman is asked about her husband, a man is asked about his rank." [42] It is also important to note that marriage was a private affair in Egypt; marriage was not considered to be a religious or political contract.[43] Even though women in Egypt were socially restricted, they experienced more sexual freedom in regards to their appearance and interactions with men in comparison to other ancient cultures. The statue of "Nykauinpu and his wife, Hemetradjet" [44] (Figure 2) shows how the women's sheath dress[45] functioned to emphasize the sexuality of the female body: the tightness of the dress and the broad shoulder straps draw attention to her round belly and full thighs. Additionally, premarital sex was regarded as socially acceptable and sensuality was encouraged for both men and women, as evidenced by this New Kingdom love poem: "Your hand is in my hand, my body trembles with joy, my heart is exalted because we walk together." [46]

In comparison to Egyptian society, the social status of women was further diminished in ancient Greece. Greek society was highly patriarchal: a woman's primary role was to produce children, in particular, male heirs.[47] Often female and agricultural fertility were commonly associated, as is seen in the socially acceptable metaphor of a husband "ploughing" his wife, suggesting that the purpose of marriage and women at large was to bear children. [48] There was immense pressure on women to birth children because men faced severe penalties if no children were produced in a marriage; for example, if a wife died and the family was childless, her dowry was to be returned to her family.[49] The social restrictions placed on women are apparent in marriage rituals when a woman is ceremoniously transferred from a father's to a husband's home, much like property.[50] Although women could in theory initiate divorce, apoleipsis, there are only two instances of this recorded in textual evidence.[51] Hipparete, the wife of Alkibiades, had to appear before an archon, a chief magistrate of a city-state, in a very formal and public procedure; this is a sharp contrast to apopempis, divorce initiated by the husband, in which the wife was simply returned back to her family.[52] Furthermore, Hipparete's attempt to divorce was unsuccessful because she was forcefully taken by husband, once again emphasizing the utter lack of control women possessed. For the most part, women were confined 
to the oikos because Greece was a decentralized empire.[53] Women could not contribute financially since the economy was trade based and there was a surplus of men to make up the labor force.[54] This inability to obtain economic power could be perceived as the direct cause of them being treated as second-class citizens. While women had some authority at home, it was greatly augmented if they had sons.

Most scholars agree that, although both were socially restricted, women in Egypt were afforded more political, economic, and sexual freedom than those in Greece.[55] As Herodotus[56], an ancient Greek historian, points out in Book II, "... the Egyptians themselves in their manners and customs seem to have reversed the ordinary practices of mankind. For instance, women attend markets and are employed in trade, while men stay at home and do the weaving." [57] The fact that a man from ancient Greece finds Egyptians to have "reversed ordinary practices" further emphasizes the dichotomy between these two ancient societies. However, the status of pregnant women in both nations is still heavily debated. To understand how pregnancy contorts a woman's ideological power, the culture of both societies, in particular religious rituals/myths and social practices, must be examined.

\section{A Women-centric View of Pregnancy in Ancient Greece}

The presence of female physicians in ancient Greece indicates that women were allocated a certain amount of expertise in medical topics and hence possessed some degree of informational power.[58] While female physicians were far and few, they were a part of the fabric of Greek society. The absence of a list of female physicians from antiquity indicates that they were an everyday part of the ancient world. [59] Practicing medicine was one of the few respectable occupations available to women, although difficult to pursue without connections or money. From the tale of Hagnodike[60], who was dubbed "the first women physician", it can be extrapolated that Athenian women began practicing medicine as early as the fourth century BC.[61] Initially, women were only permitted to be midwives, but by the end of the fifth century, a distinction between female doctors and midwives appeared. One example of a female doctor is Phanostrate[62], who was called a "midwife and doctor" [63] on her gravestone. Interestingly, the word iatros is used, which is a typical word for "doctor" in Greek, suggesting that there might have been no distinction between male and female doctors.

A section in Plato's Republic captures the prevailing attitudes towards female physicians in antiquity and supports the notion of equality between female and male physicians. Plato argues that in the ideal state, people should be assigned to jobs based on their given aptitude for the profession rather than their physical characteristics.[64] To defend his argument, he points to the existence of female doctors and the fact that women are physicians because they are skilled at medicine. It is important to notice that Plato is not trying to convince people that there should be female physicians - he is using them as an example to prove his point. As Pomeroy points out, "Plato did not have to prove women's aptitude for the medical profession. On the contrary, his case rests on the existence of female physicians in the Athens of his own day." [65] He writes that a "man skilled in medicine and a woman skilled in medicine - in respect to their minds - have the same nature," [66] suggesting that he does not view intellect to depend on gender. Through the analysis of Plato's Republic, one can conclude that little distinction was made between male and female physicians, especially in the gynecological/obstetrics realm. It can be interpreted that women in Classical Greece possessed some degree of ideological power since the empire had faith in their medical abilities.

The presence and acceptance of female physicians suggests that because women could choose to be physicians, they could also choose to actively participate in their own prenatal health care. The fact that women were generally granted more power with regards to medicine[67] and personal health suggests that pregnant women in Greece, because they were pregnant, might have possessed more ideological power than nonpregnant women. The analysis of the Hippocratic corpus, a body of Greek medical writings from the fifth and fourth centuries which primarily concentrate on obstetrics and gynecology, provides insight into how pregnant women were viewed by medical professionals.[68] Examining the Diseases of Women and the Nature of the Child in particular suggest that pregnancy garnered women more respect and freedom than usual.

In The Diseases of Women, Hippocrates portrays carrying and delivering a child as a difficult, intricate 
task. By emphasizing the hardship undergone by women during menses and childbirth itself, he brings attention to the sacrifices women make. Hippocrates writes that "it requires much attention and knowledge to bring a child to term and provide for its nourishment in the uterus, and then to give birth to it" [69], depicting carrying a child as a skilled task. This indicates the great responsibility endowed upon women and the competency they must possess to bring a child into the world. In another treatise, the Diseases of Young Girls, Hippocrates observes that young girls often suffer from a maddening "sickness" that arises from puberty. His proposed treatment: "if they become pregnant, they become healthy." [70] Although its demeaning attitude must be acknowledged, it is worth noting that pregnancy was perceived as a cure to the irrational temperament of girls, thereby implying that pregnant women were sensible. These sources support the notion that the Greeks, at the very least, respected pregnant women and showed appreciation for their physical contributions.

In The Nature of the Child, Hippocrates contradicts his sentiment on abortions expressed in the Hippocratic Oath. In his Oath, he swears to "not give to a woman a pessary to cause abortion" but that he "will keep pure and holy in both my life and art".[71] His statement implies that he considered abortion to be an impure, unsacred act that should be avoided. However, in the The Nature of the Child, Hippocrates discusses abortion in a matter of fact tone to explain fetus articulation; he does not make any indication to the unethicalness of the procedure. "Many women have aborted a male fetus little before 30 days, and it showed not articulation, whereas fetuses aborted after...showed articulation." [72] This contradicts his opinion in the Hippocratic Oath and supports the evidence from early Greek medical treatises that abortion was only avoided by physicians because of the concern for the dangers involved.[73] This text indicates that abortion was an option available to Greek women, and while not encouraged, remained their choice - one can reason that pregnant women had some control over their own bodies.

In comparison to other points of time in a Greek female's life, such as when she is forced to marry or manage the household, pregnancy afforded her moderately more power over her body and actions. From the attitudes toward female physicians and pregnant women, it can be assumed that the Greeks viewed women to be knowledgeable with regards to childbirth and women's health as a whole, which allowed pregnant women to indirectly gain a perceived higher educational and social status than non-pregnant women.

\section{Ancient Egyptian Society Viewed Men as Creators}

In contrast to Greece, there is much evidence that suggests pregnant women in Egypt might have been more restricted than their non-pregnant counterparts. Contrary to many scholars' beliefs, in ancient Egypt, a woman's power did not stem from her ability to produce children. In fact, the opposite might have been true - a woman's association to fertility diminished her autonomy.[74] Unlike most other ancient cultures, Egypt afforded women many legal, political, and sexual freedoms, such as, in rare cases, ruling the country.[75] Nevertheless, Egyptians designated the power of procreation as a purely male characteristic, which contradicts the typical Western belief.

This Western belief is evident in phrases such as "Mother Earth", European women's dresses that accentuate the belly, and that fact that women were typically labeled as "barren", rather than men. The Western association of women with fertility derives from Classical antiquity.[76] Although some Greek medical views contradicted this belief, folk myths, such as Zeus swallowing his wife, Metis, to be able to birth his daughter, revolve around female fertility.[77] In addition, it is important to note that fertility of the earth is under the power of the female goddess, Demeter. According to myth, when Persephone, Demeter's beloved daughter, is snatched to the underworld by Hades, the earth becomes a barren wasteland.[78] The fertility of the earth as well as of women, which were typically tied together, seem to be centered in a woman herself, Demeter.[79] However, the female-centric model of fertility is not accurate for Egypt.

The Egyptians' association between birthing and men is evident in their language and myths. The Egyptian verb for conceiving literally means to "receive" or "take", indicating that the woman receives the formed infant from the man.[80] This notion is also supported by Akhenaton's Hymn to Aton depicting god to "place the seed" in the women and "make the sperm into a person." [81] It is also important to acknowledge 
the role of semen in numerous conception myths. In the tale of Setne Khamwas and the Magic Book, Setne, a priest of the god Ptah, falls in love with a woman, Tabubu.[82] One particular line reads, "She received [the fluid of] conception from him" [83], suggesting that men provided women with the ability to give birth. Another example comes from the Contendings of Horus and Seth, where Isis is described to "put the seed of Horus on the lettuce that Seth ate every day, and Seth arose pregnant...." [84] The ejaculate of Horus is clearly the root of conception; the symbol of "lettuce" is also quite telling considering the fact that the plant's "milky white sap" [85] was connected to fertility. These cultural facets suggest that while pregnant women had power over many aspects of their lives, this power was due to the fact that they were female citizens, not the fact that they could beget children, which was an ability prescribed to men.

In Egyptian religion, the supernatural beings that were responsible for creative fertility were predominately male. [86] One such representation of these divinities was as a bull or ram, which were considered to be masculine animals; such is the case with the ram-headed god Khnum creating children through his potter's wheel[87] or the labeling of a divine king as "The Strong Bull of the Gods" [88] because of his ability to produce successors. Egyptians believed that "male creativity in fertility" [89] was so powerful that they had the ability to dictate the sex of the child they produced. This could provide an possible explanation as to why female infanticide was more prevalent in ancient Greece in comparison to Egypt, which lacks evidence to support the presence of this practice.[90] According to Zimmern, the practice of exposing female infants existed primarily because "the provision of a dowry weighed heavily on a Greek father's mind." [91] However, Patterson debates that females were considered a "valuable social and political asset", hence negating the impact of the expenditure associated with a dowry and reason for infanticide.[92] Regardless of the frequency and extent to which infanticide was practiced in Greece, the absence of it in Egypt could at least be partly ascribed to the fact that children were thought to be the result of the creative powers of men.

The debilitating effects of pregnancy on a woman's ability to exercise her social power can been seen in the instructions of Ptahhotep. The passage suggests that socially, wives were viewed as dependents who needed to be constantly taken care of and pampered. The author insists that to avoid conflict husbands must provide their wives with ample love, food, and clothes. He also refers to a woman as a "fertile field" maintained "for her lord." [93] This indicates that while a woman's "usefulness" stems from her ability to bear children, this ability ultimately hinders her autonomy and makes her a subordinate. This implies that pregnant women might have had the least power, compared to other subgroups of women in Egypt, because she was, to some extent, bearing the fruits of labor of "her lord." [94]

As mentioned previously, the youthfulness and sensuality of women is typically captured in ancient Egyptian dress and art.[95] Representations of those perceived as unideal, i.e. those who were not considered beautiful or slender, such as older women who had gone through pregnancy, were rare.[96] Robins comments that "neither pregnancy nor the spreading waistline that many women must have had after years of bearing children is part of the image." [97] The sagging breasts and loose skin that are present after childbirth and breastfeeding were marker of age and a reminder that a woman no longer embodied culturally accepted beauty standards.[98] It is possible that pregnant women held less social clout than their non-pregnant counterparts because they were "undesirable" to society, thereby depriving them of the benefits of employing their sexual power for social gain.

\section{Artwork and other Pregnancy-related Artifacts Show Cultural Values}

From inspection, it can be reasoned that pregnant women in Egypt were more socially hindered than the average Egyptian woman or Greek pregnant woman. For Egyptian women, the power that they inherited by being female citizens is somewhat stripped away during pregnancy. However, it is plausible that in replacement of this lost ideological power they gain something else: supernatural powers, which make them almost god-like. The birth-brick recently found in South Abydos is evidence of this (Figure 3).[99]

Birthing bricks served both functional and spiritual roles in Ancient Egyptian society. They were one of the many magical items used to protect the mother and the infant during childbirth while also acting as a physical support for a woman in labor.[100] Birthing bricks often had images decorating its faces. On this 
particular brick, the scene painted depicts a mother, child, and two female attendants (Figure 3). It merges the two stages of the birthing process: the delivery itself (shown through the servants assisting the mother) and the successful birth (suggested by the child playing in the mom's arms).

This birthing brick makes many allusions to the supposed divinity of the mortal mother. Firstly, the mother and child sit on a grand, divine throne rather than the customary four-legged chair.[101] The mother's hair is painted blue, which is a symbol of godliness in Egyptian art[102]; this particular blue is dubbed as "lapislazuli" [103] and is often associated with solar rebirth. The color matches the blue hair of the divine Hathor figures surrounding the mother, suggesting that the mother could represent Hathor, the goddess of fertility and birth.[104] The baby boy the mother is holding is presented with black hair, indicating that he is a mere human. This presentation of the birth suggests that the artist believed the concepts of delivery and motherhood to be of a divine nature. It is especially telling that the mother's and son's hair colors differ, suggesting that the mother's divinity is independent of the child's status and vice versa. This separation of maternal and child divinity is not present in Greek myth, as can be read in Hera's objection to returning the body of Hector to the Trojans in the Iliad: “... if indeed you gods grant the same honor to Achilles and to Hector. Hector is but mortal and was suckled at a woman's breast, but Achilles is the child of a goddess...".[105] Although both are heroes, Hector's mother, Hecuba, is a mortal while Achilles's mother is the goddess Thetis. Hector's mortal heritage is portrayed to have been tied to the humanness of his mother, and to some extent, be a result of his consuming his mother's breastmilk.[106] On the birthing brick, the fact that divinity is assigned only to the mother indicates that Egyptians might have believed a pregnant woman to have an intrinsic, almost magical, power.[107]

While at face value this newfound power might seem beneficial to women, there is the possibility that ultimately, it isolates pregnant women from the rest of society and pronounces their otherness. This sort of isolation is visible when women are menstruating; an ostracon discovered in Medinet Habu refers to a $s t$ $h m w t$, which is best interpreted as "the women's place while they were having their menstruation." [108] The Satire of Trades indicates that washermen were regarded to be low ranking members of society because "he (the washerman) sets himself to do the loincloth of a woman having her period." [109] The connection between the absence of menstruation and pregnancy[110] suggests that pregnant women also might have received a similar treatment. In addition, the strong association between men and procreation made by the Egyptians renders anyone else involved, such as the women, a subordinate and executor of the man's will.[111] The divinity of the woman portrayed in the South Abydos birthing brick could stem from the fact that she is the vessel of the godly man, or in other words, divine by proxy. In some sense, her emphasized transition from mortal to divine serves to reinforce what power she has lost because of the transition itself. While she is divine, her identity becomes reduced to child-bearer rather than the "storm" [112] she once was.

It is important to note that while there are many statues and reliefs of pregnant women and birthing scenes from ancient Egypt, very little artwork depicting pregnancy has been found dating back to Classical Greece. In the few instances that pregnancy was represented in art, it was mainly in relation to death.[113] This is mostly likely because maternal mortality was prevalent in the ancient world, with rates estimated to be as high as $14 \%$, due to a variety of conditions including hemorrhage, pelvic deformity, eclampsia.[114] An Attic grave relief made of pentelic marble dating back to $330 \mathrm{BCE}$ shows a woman dying in childbirth surrounded by a female mourner, an old nurse, and a servant (Figure 4).[115] The nurse holds the woman's hand while the servant supports her weight as she leans on what appears to be a couch. The word "daughter" is inscribed above the dying women. It can be assumed that the purpose of this grave relief was to pay homage to this woman in her role as "daughter", not as an almost mother. While there is evidence of childbirth, the focus of the scene is on the sadness founded on the death of this daughter, not her unborn child. Although pregnancy is somewhat alluded to in this art, it is only because of its association with the dead; it is not honored or celebrated here or in most other Classical Greek art.

The lack of pregnancy-related artifacts suggests that Greeks might have viewed feminine health issues to be private and, much like women, as entities to be confined to the oikos.[116] The restriction of women to the domestic sphere is evident in the requirement of a kyrios and the barring of women from economic and 
political activities.[117] This notion that women belonged exclusively to the home could have affected the Greek approach to women's health: medical information concerning women was not to be shared outside immediate family and certainly not in a public place.[118] These principles would have prevented artists from portraying parturition scenes, or, at the very least, prevented the distribution of such artworks. Although pregnancy afforded Greek women many freedoms, the limited representation of it in artwork is a reminder of the immense social constraint placed on women. It is probable that ancient Greek society reduced the number of references made to a woman's ideological power through the forgoing of gynecologically themed artwork.

\section{Conclusions}

The mystical nature of pregnancy captured the spiritual, medical, and political interests of the ancients. The inability to conceive had enormous social implications for both men and women, as is evidenced by this line from a letter written in the Twentieth Dynasty of Egypt (1189-1077 BC) found in Deir el-Medina: "You are not a man since you are unable to make your wives pregnant like your fellow men." [119] As shown in this analysis of textual, archeological, and artistic evidence, the social power of pregnant and non-pregnant women in ancient Egypt and Greece widely differed.

With regards to non-pregnant women, political, legal, and economic institutions controlled their access to social power in these societies. A prime example of this is the ability to initiate divorce, which was a right that, unlike Greek women[120], Egyptian women enjoyed[121], hence allowing them to have some say in their relationships and quality of life. It can be inferred that the inability of Greek women to contribute economically and the social view of their worth to be tied to their roles as child-bearers[122] further reinforced the unimportance of non-pregnant individuals in society. However, the importance placed on reproduction lays the groundwork for why pregnancy played such a pivotal role in determining a woman's access to ideological power in particular.

In Greece, due to the association of females with fertility[123], pregnancy increased a woman's ideological power, thereby allowing women to gain social worth and status to some degree. The source of this power can be attributed to Greek myths such as the Rape of Persephone[124] and birth of Athena[125] that place the power of procreation with women. However, viewing ideological power in Egypt through this Western lens, which is an error often made in the literature, causes one to erroneously ignore the alternate reality: Egyptians viewed conception to be the result of the physical and creative powers of men.[126] The association between males and fertility causes a woman's political and sexual power to moderately diminish when she becomes pregnant as she 1) is viewed to be undesirable by society[127] and 2) functions as the "fertile field of her lord." [128] Through the evidence presented above, it can be concluded that pregnancy afforded Greek women independence, or at the very least, some informational authority while it reduced the significance of Egyptian women to birthing vessels. From this analysis, it can be determined that the effect of pregnancy on women's social power in the ancient world is primarily determined by cultural factors such as religious myths and customs.

\section{Appendix:}




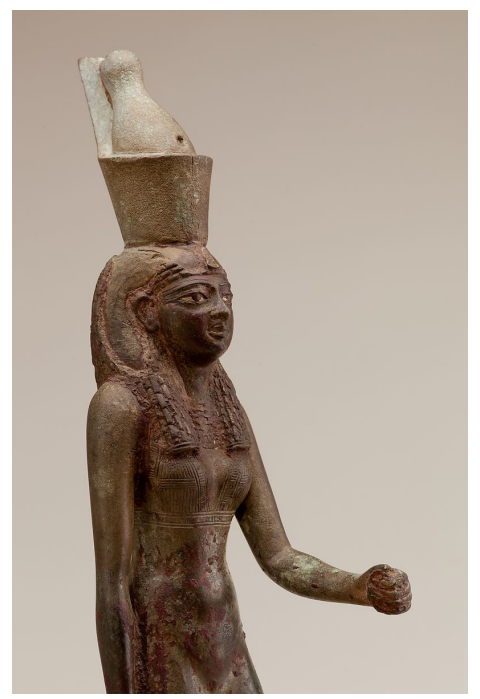

Figure 1: Statue of Mut of Nekhbet from the Third Intermediate Period-Kushite Period, ca. 1090-664 B.C. is on view at The Met Fifth Avenue Gallery 125. It is made of cupreous alloy.

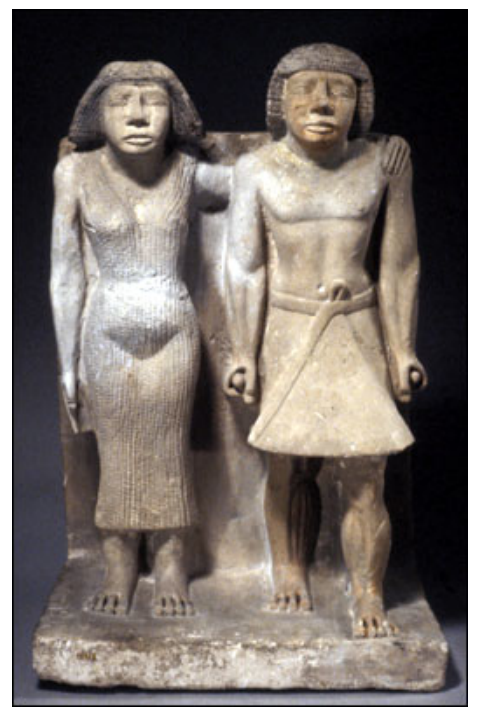

Figure 2: Statue of Nykauinpu and his wife, Hemetradjet from the Old Kingdom, ca. 2477-2466 BC is a part of the Oriental Institute at the University of Chicago's collection. It is made of limestone, the main building stone of Egyptians, and pigment. 


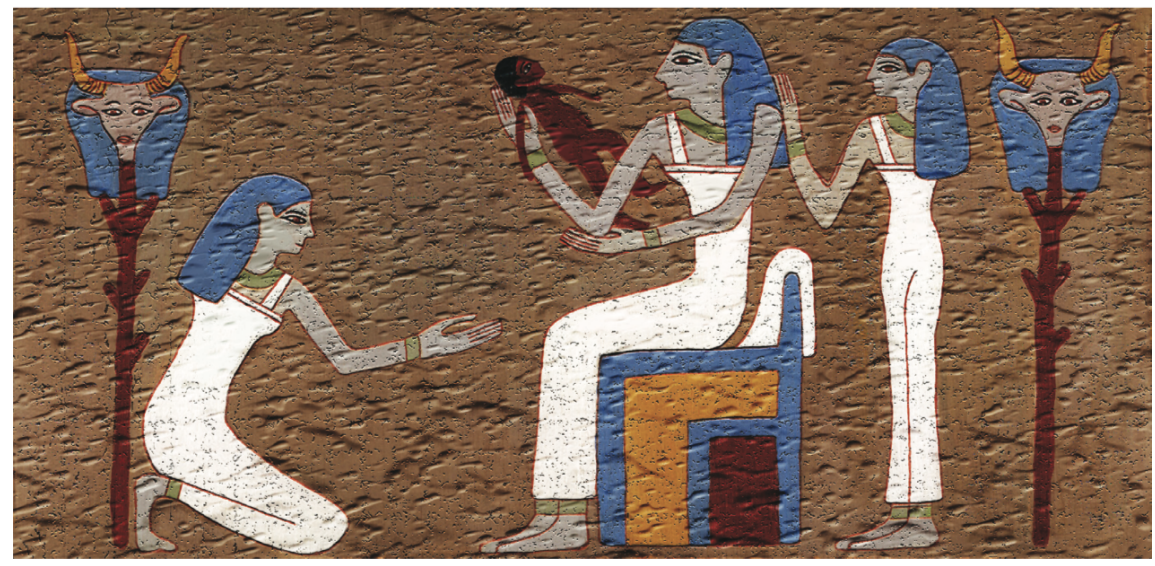

Figure 3: Painting by Jennifer Wegner, reconstructing Side A of the birthing brick found in South Abydos, portraying the mother, child, and two Hathors. It is a decorated mud brick that was found only partially intact.

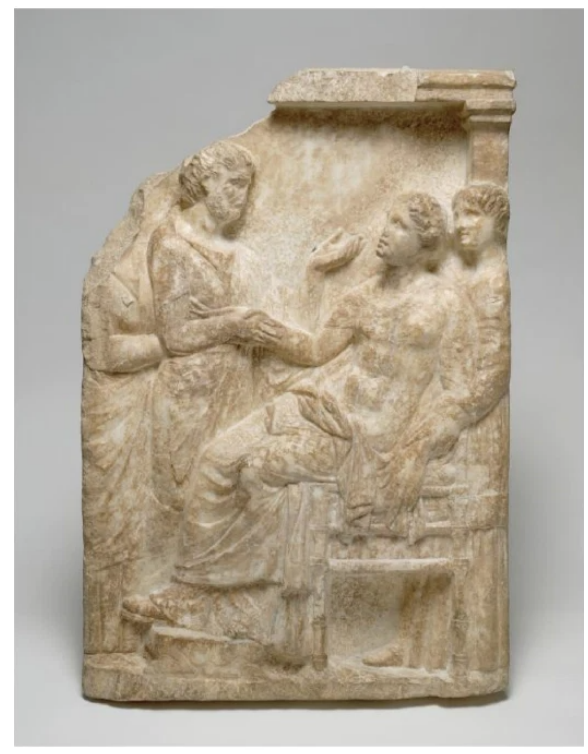

Figure 4: Attic grave relief depicting a woman dying in childbirth, dating back to $330 \mathrm{BC}$; it is housed in Harvard Art Museums. It is made of pentelic marble, which was often employed to create most monuments in Classical Athens.

\section{Endnotes:}

[1] Tsoucalas, Gregory \& Sgantzos, Markos. (2017). Calculating Pregnancy's Duration in Ancient Greece. Gestational, or Fetal Age?. Obstet Gynecol Int J. 6. 00209. 10.15406/ogij.2017.06.00209.

[2] Robertson, Noel. "Greek Ritual Begging in Aid of Women's Fertility and Childbirth." Transactions of the American Philological Association (1974-) 113 (1983): 143-69. 
[3] Ridgway, Brunilde Sismondo. "Ancient Greek Women and Art: The Material Evidence." American Journal of Archaeology 91, no. 3 (1987): 399-409.

[4]E. Iversen, Papyrus Carlsberg No. VIII with Some Remarks on the Egyptian Origin of Some Popular Birth Prognoses, Copenhagen (1939).

[5] Adamson, P. B. "Some Rituals Associated with Parturition in Antiquity." Folklore 96, no. 2 (1985): 176-83. Explanation on pg.176.

[6] Mann Michael, The Sources of Social Power, Cambridge: Cambridge University Press (1986), pg.2.

[7] Ibid, pg.6.

[8] Whitmeyer, J. M. "Mann's Theory of Power - A (Sympathetic) Critique." The British Journal of Sociology 48, no. 2 (1997): 210-25. Comment made on pg.210.

[9] Collins, Randall. "Marx, Weber, and Mann." Contemporary Sociology 42, no. 4 (2013): 482-84. Comment on pg.482.

[10] Mann (1986), pg.23.

[11] Johnson, Janet H. "The legal status of women in ancient Egypt." In Mistress of the House, Mistress of Heaven: Women in Ancient Egypt, New York: Hudson Hills Press in association with Cincinnati Art Museum (1996). See pg.175.

[12] Unknown, Statuette of Mut or Nekhbet, ca.1070-664 B.C. Third Intermediate Period-Kushite Period on view at The Met Fifth Avenue in Galley 125.

[13] te Velde, Herman. "Mut", in Redford, D. B. (ed.), The Ancient Gods Speak: A Guide to Egyptian Religion, New York: Oxford University Press (2003). See pg.238.

[14] Unknown, Statue of Nakht-mut, in Mistress of the House, Mistress of Heaven: Women in Ancient Egypt, ed. Anne Capel, New York: Hudson Hills Press (1996). Translated on pg.182.

[15] Johnson (1996).

[16] Brewer, Douglas J and Emily Teeter. Seminar is extracted from Chapter 7 of Egypt and the Egyptians, Cambridge University Press (2001).

[17] Ferrero, Mario. "The Rise and Demise of Theocracy: Theory and Some Evidence." Public Choice 156, no. 3/4 (2013): 723-50. See pg.723-724.

[18] O'Connor, David. "Political Systems and Archaeological Data in Egypt: 2600-1780 B.C." World Archaeology 6, no. 1 (1974): 15-38. See pg.15.

[19] Wenke, Robert J. "Egypt: Origins of Complex Societies." Annual Review of Anthropology 18 (1989): 129-55. See map on pg.131.

[20] Fontaine, Carole R. "A Modern Look at Ancient Wisdom: The Instruction of Ptahhotep Revisited." The Biblical Archaeologist 44, no. 3 (1981): 155-60. Comment made on pg.156.

[21] Roccati, Alessandro. "Dating Ptahhotep's Maxims (Note Letterarie VI)." Orientalia, NOVA SERIES, 83, no. 2 (2014): 238-40. Comment on pg. 238.

[22] Fox, Michael V. "Ancient Egyptian Rhetoric." Rhetorica: A Journal of the History of Rhetoric 1, no. 1 (1983): 9-22. See pg. 10.

[23] Unknown, Instructions of Ptahhotep, in Mistress of the House, Mistress of Heaven: Women in Ancient Egypt, ed. Anne Capel. New York: Hudson Hills Press (1996). Translated on pg.175.

[24] Ibid. 
[25] Ibid.

[26] A. L. Boegehold, "Perikles' Citizenship Law of 451/0 BC", in Athenian Identity and Civic Ideology, ed. A. L. Boegehold and A. C Scafuro, Baltimore (1994). According to Roy, J. "'Polis' and 'Oikos' in Classical Athens." Greece \&5 Rome 46, no. 1 (1999): 1-18, "by making descent from the mother as important as descent from the father for a child's inherited status, the law may well also have given the wife a greater importance within the household."

[27] S. Blundell, Women in Ancient Greece, London (1995). See pg.128.

[28] For more information on Athenian democracy see Jones, A. H. M. "The Athenian Democracy and Its Critics." The Cambridge Historical Journal 11, no. 1 (1953): 1-26.

[29] King Erichthonios was born from an attempted rape of the goddess Athena by Hephaistos, hence causing Athena to be viewed as the "divine mother" of Athenian royal line. For further explanation, refer to Spaeth, Barbette Stanley. "Athenians and Eleusinians in the West Pediment of the Parthenon." Hesperia: The Journal of the American School of Classical Studies at Athens, no. 60 (1991): 331-362.

[30] R. Parker, "Myths of Early Athens", in Interpretations of Greek Mythology, ed. J. Bremmer, London and New York (1988).

[31] Hesiod, Theogony, in "THE POSITION OF ATTIC WOMEN IN DEMOCRATIC ATHENS," Greece and Rome 61, no. 2 (2014); see pg.176 for translation.

[32] Ibid.

[33] Pritchard, David M, "THE POSITION OF ATTIC WOMEN IN DEMOCRATIC ATHENS," Greece and Rome 61, no. 2 (2014): 174-93.

[34] J. Gould, 'Law, Custom and Myth: Aspects of the Social Position of Women in Classical Athens', Journal of Hellenic Studies 100 (1980). See pg.45.

[35] Pericles, Funeral Oration, in "THE POSITION OF ATTIC WOMEN IN DEMOCRATIC ATHENS," Greece and Rome 61, no. 2 (2014). See pg.178 for translation.

[36] Allison, Craig Y. Michigan Law Review 89, no. 6 (1991): 1610-617. See pg.1610.

[37] Pritchard (2014).

[38] Ibid.

[39] Johnson (1996), pg.176.

[40] Ibid.

[41] The New Kingdom was a period between 16-11BC. For further reading, see Hagen, Fredrik. "'The Prohibitions": A New Kingdom Didactic Text." The Journal of Egyptian Archaeology 91 (2005): 125-64.

[42] Johnson (1996), pg.176.

[43] Brewer, Douglas J and Emily Teeter (2001).

[44] Unknown, Nykauinpu and his wife, Hemetradjet. 2477-2466 BCE. Sculpture. Oriental Institute, University of Chicago.

[45] More information on ancient Egyptian women's dress can be found in B. M. C. "The Dress of the Ancient Egyptians: I. In the Old and Middle Kingdoms." The Metropolitan Museum of Art Bulletin 11, no. 8 (1916): 166-71.

[46] Ancient Egyptian Literature, Volume II: New Kingdom, Lichtheim 1976: 182, University of California Press (2006) 
[47] "Thus, the primary duty of Athenian women of childbearing age was to produce little Athenians" on pg.119 in O'Neal, William J. "The Status of Women in Ancient Athens." International Social Science Review 68, no. 3 (1993): 115-21.

[48] Robert Parker, Polytheism and Society at Athens, Oxford (2005). See pg.276.

[49] Bardis, Panos D. "The Ancient Greek Family." Social Science 39, no. 3 (1964): 156-75. See pg.160.

[50] Pritchard (2014).

[51] Louis Cohn-Haft. "Divorce in Classical Athens." The Journal of Hellenic Studies 115 (1995): 1-14.

[52] Ibid, pg.4.

[53] Berent, Moshe. "'STASIS “, OR THE GREEK INVENTION OF POLITICS." History of Political Thought 19, no. 3 (1998): 331-62. See pg.333.

[54] Morris, Ian. "Economic Growth in Ancient Greece." Journal of Institutional and Theoretical Economics 160, no. 4 (2004): 709-42. See pg.732.

[55] Further insight in the legal rights of ancient Egyptian women can be found in Allam, S. "Women as Holders of Rights in Ancient Egypt (During the Late Period)." Journal of the Economic and Social History of the Orient 33, no. 1 (1990): 1-34.

[56] For more information on Herodotus and his study of Egypt, see Lloyd, Alan B. "Herodotus' Account of Pharaonic History." Historia: Zeitschrift Für Alte Geschichte 37, no. 1 (1988): 22-53.

[57] Herodotus, Historiae II: 35, in Dieleman, Jacco. "Fear of Women? Representations of Women in Demotic Wisdom Texts." Studien Zur AltÃ Ø̊gyptischen Kultur 25 (1998): 7-46. See pg.7.

[58] Pomeroy, Sarah B., "Technikai kai Mousikai: The Education of Women in the Fourth Century and in the Hellenistic Period," American Journal of Ancient History 2 (1997), 51-68.

[59] Holt Parker, Women Physicians in Greece, Rome, and the Byzantine Empire, in Women Healers and Physicians: Climbing a Long Hill, ed. Lilian Furst, Lexington: University of Kentucky Press (1997). See pg.132.

[60] KING, HELEN. "AGNODIKE AND THE PROFESSION OF MEDICINE." Proceedings of the Cambridge Philological Society, NEW SERIES, no. 32 (212) (1986): 53-77.

[61] Pomeroy, Sarah B. "Plato and the Female Physician." The American Journal of Philology 99. No. 4 (1978): 496-500.

[62] Refer to pg.299 of Kosmopoulou, Angeliki. "'Working Women': Female Professionals on Classical Attic Gravestones." The Annual of the British School at Athens 96 (2001): 281-319.

[63]Holt Parker, 133.

[64] Pomeroy (1978)

[65] Ibid. pg.500

[66] Plato, Republic, Volume I: Books 1-5, ed. Christopher Jones (Cambridge: Harvard University Press, 2013).

[67] For works of female medical writers, read PARKER, HOLT N. "GALEN AND THE GIRLS: SOURCES FOR WOMEN MEDICAL WRITERS REVISITED." The Classical Quarterly 62, no. 1 (2012): 359-86.

[68] Hanson, Ann Ellis. "Hippocrates: "Diseases of Women 1"." Signs 1, no. 2 (1975): 567-84.

[69] Hippocrates, Diseases of Women, ed. and translated by Jeffrey Henderson. Loeb Classical Library 538. Cambridge: Harvard University Press (2019). See pg.71. 
[70] Hippocrates, Rebecca Flemming, and Ann Ellis Hanson. "Hippocrates' "Peri Partheni Á 'n' (Diseases of Young Girls): Text and Translation.-Early Science and Medicine 3, no. 3 (1998): 241-52. See pg. 251-252.

[71] Hippocrates, The Oath, ed. and translated by Jeffrey Henderson. Loeb Classical Library 147. Cambridge: Harvard University Press (2019). See pg. 299.

[72] Hippocrates, Nature of the Child, ed. and translated by Jeffrey Henderson. Loeb Classical Library 520. Cambridge: Harvard University Press (2019). See pg. 51.

[73] Hanson, Ann Ellis. "Hippocrates: "Diseases of Women 1"." Signs 1, no. 2 (1975): 567-84. See pg. 567.

[74]Ann Roth, "Father Earth, Mother Sky: Ancient Egyptian Beliefs about Conception and Fertility", in Reading the Body: Representations and Remains in the Archaeological Record, ed. Alison Rautman, Philadelphia: University of Pennsylvania Press (1999). See pg.187.

[75] Hatshepsut ruled Egypt as a pharaoh during Eighteenth Dynasty of Egypt, between 1507-1458 BC. See the following article for further reading on her: MARGETTS, EDWARD L. "THE MASCULINE CHARACTER OF HATSHEPSUT, QUEEN OF EGYPT." Bulletin of the History of Medicine 25, no. 6 (1951): $559-62$.

[76] Roth (1999), pg.188.

[77] Zeitlin, Froma I. "THE DYNAMICS OF MISOGYNY: MYTH AND MYTHMAKING IN THE ORESTEIA." Arethusa 11, no. 1/2 (1978): 149-84. See pg.180.

[78] For a more detailed analysis of the myth, see Lincoln, Bruce. "The Rape of Persephone: A Greek Scenario of Women's Initiation." The Harvard Theological Review 72, no. 3/4 (1979): 223-35.

[79] Nixon, Lucia. "The Cults of Demeter and Kore." In Women in Antiquity: New Assessments, ed Richard Hawley and Barbara Levick, 75-96. New York: Routledge (1995). See pg.92.

[80] Roth (1999), pg.189.

[81] Akhenaton's Hymn to Aton in Ibid.

[82] Rutherford, Ian. "Kalasiris and Setne Khamwas: A Greek Novel and Some Egyptian Models." Zeitschrift FA $\frac{1}{4} r$ Papyrologie Und Epigraphik 117 (1997): 203-09.

[83] TEETER, EMILY. "The Body in Ancient Egyptian Texts and Representations (Plate 6)." The Bulletin of the American Society of Papyrologists 37, no. 1/4 (2000): 149-70. See pg.163.

[84] Contendings of Horus and Seth in Locke, Norman. "A Myth of Ancient Egypt." American Imago 18, no. 2 (1961): 105-28. See pg.111.

[85] Teeter (2000), pg.163.

[86] Roth (1999), pg.190.

[87] Vergilian Society Egypt Tour Egyptian Encore, Vergilius 57 (2011), 164-166.

[88] Wainwright, G. A. "The Bull Standards of Egypt." The Journal of Egyptian Archaeology 19, no. 1/2 (1933): 42-52. See pg.51.

[89] Roth (1999), pg.190.

[90] Brewer, Douglas J and Emily Teeter (2001)

[91] Wayne Ingalls. "Demography and Dowries: Perspectives on Female Infanticide in Classical Greece." Phoenix 56, no. 3/4 (2002): 246-54. See pg.250.

[92] Patterson, Cynthia. "'Not Worth the Rearing “: The Causes of Infant Exposure in Ancient Greece." Transactions of the American Philological Association (1974-) 115 (1985): 103-23. See pg.120. 
[93] Unknown, Instructions of Ptahhotep, 175.

[94] Ibid.

[95] For an analysis on Egyptian clothing read Riefstahl, Elizabeth. "A Note on Ancient Fashions: Four Early Egyptian Dresses in the Museum of Fine Arts, Boston." Boston Museum Bulletin 68, no. 354 (1970): 244-59.

[96] John R. Baines, Fecundity Figures: Egyptian Personification and the Iconology of a Genre (Warminster, 1985), 125.

[97] Gay Robins, Women in Ancient Egypt, London (1993). See pg.180.

[98] Sweeney, Deborah. "Forever Young? The Representation of Older and Ageing Women in Ancient Egyptian Art." Journal of the American Research Center in Egypt 41 (2004): 67-84. See pg.69.

[99] Unknown, Decorated Birth-Brick from South Abydos, in Archaism and Innovation: Studies in the Culture of Middle Kingdom Egypt, ed. David Silverman, New Haven: Yale University Press (2009).

[100] Roth, Ann Macy, and Catharine H. Roehrig. "Magical Bricks and the Bricks of Birth." The Journal of Egyptian Archaeology 88 (2002): 121-39. See pg.129.

[101] F. Fetten, "Der agyptische Stuhl" (1982), comments on the symbolism of chairs and thrones on pgs.218228.

[102] H. Kees, "Farbensymbolik in agyptischen religiosen Texten (1943), 413-79.

[103] Baines, John. "Color Terminology and Color Classification: Ancient Egyptian Color Terminology and Polychromy." American Anthropologist, New Series, 87, no. 2 (1985): 282-97. See pg.284.

[104] Wegner, Jospeh. Decorated Birth-Brick from South Abydos: New Evidence on Childbirth and Birth Magic in the Middle Kingdom in Archaism and Innovation: Studies in the Culture of Middle Kingdom Egypt, ed. David Silverman, New Haven: Yale University Press (2009). See pg.457.

[105] Homer, Iliad, translated by A.T. Murray. Loeb Classical Library 170, Cambridge: Harvard University Press (1924).

[106] Murnaghan, Sheila. "Maternity and Mortality in Homeric Poetry." Classical Antiquity 11, no. 2 (1992): 242-64. See pg.245.

[107] Wegner (2009), pg.457.

[108] T. G. Wilfong, "Menstrual Synchrony and the 'Place of Women' in Ancient Egypt", in Gold of Praise: Studies on Ancient Egypt in Honor of Edward F., ed. E. Teeter, J. Larson. Chicago: Oriental Institute of the University of Chicago, 1999, pg.419-434.

[109] Frandsen, PaulÂ John. "The Menstrual "Taboo" in Ancient Egypt-Journal of Near Eastern Studies 66, no. 2 (2007): 81-106. See pg.100.

[110] "He slept with] me again and again, and we loved each other. When my time of hsmn (period) came, I made no more hsmn", from Setne I in Ibid.

[111] For further examples: "She is a fertile field for her lord", Instructions of Ptahhotep; "The male member to beget, the female womb to conceive, and increase generations in Egypt", Hymn to Khonsu in Lichtheim, Miriam, and Joseph G. Manning. Ancient Egyptian Literature: Volume III: The Late Period. University of California Press (2006).

[112] Unknown, Instructions of Ptahhotep, 175.

[113] Ridgway, Brunilde Sismondo. "Ancient Greek Women and Art: The Material Evidence." American Journal of Archaeology 91, no. 3 (1987): 399-409. See pg.403. 
[114] Liston, Maria A., and John K. Papadopoulos. "The "Rich Athenian Lady"Was Pregnant: The Anthropology of a Geometric Tomb Reconsidered.-Hesperia: The Journal of the American School of Classical Studies at Athens 73, no. 1 (2004): 7-38. See pg.20.

[115] Unknown, Attic Grave Stele: Woman Dying in Childbirth. 330 BCE. Sculpture. Harvard Art Museums, Cambridge.

[116] Pritchard (2014).

[117] "Since women's roles were most productively played out in the private world of the household, where male and female were integrated, it was only men who could operate effectively in the public world with its polarised and hierarchical system of gender." In Foxhall, Lin. "Household, Gender and Property in Classical Athens." The Classical Quarterly 39, no. 1 (1989): 22-44. Comment on pg.31.

[118] Refer back to Pericles' comment that a wife's "glory is great... if there is the least possible talk of [her] among men either for praise or blame" in Prichard (2014).

[119] Mark Masterson, Nancy Sorkin Rabinowitz, James Robson, Sex in Antiquity: Exploring Gender and Sexuality in the Ancient World. Rewriting antiquity. New York: Routledge (2015).

[120] Louis Cohn-Haft. "Divorce in Classical Athens." The Journal of Hellenic Studies 115 (1995): 1-14.

[121] Brewer, Douglas J and Emily Teeter (2001).

[122] O'Neal, William J. "The Status of Women in Ancient Athens." International Social Science Review 68, no. 3 (1993): 115-21.

[123] Roth (1999).

[124] Spaeth (1991).

[125] Zeitlin (1978).

[126] Roth (1999).

[127] Robins (1992).

[128] Unknown, Instructions of Ptahhotep. 